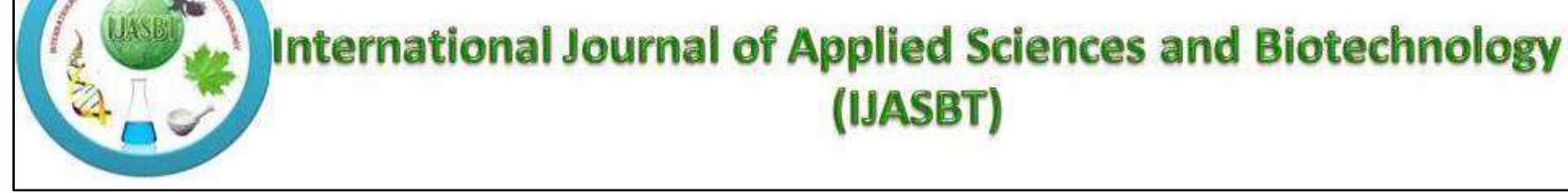

Research Article

\title{
RESPONSE OF THE MOST PROMISING WHEAT GENOTYPES WITH DIFFERENT NITROGEN LEVELS
}

\author{
N. Rawal*, D. Chalise and N. Khatri \\ Nepal Agricultural Research Council, Nepal \\ *Corresponding author's email: nabin_rawal@yahoo.com
}

\begin{abstract}
Field experiments were conducted during winter seasons of 2013 and 2014 on the alkaline and silty loam soils of NWRP, Bhairahawa to study the interaction of the most promising wheat genotypes with different nitrogen levels under different agro-ecological zones and recommend the appropriate dose of nitrogen for newly released varieties. The experiment was laid out in split plot design: four nitrogen levels $(0,50,100$ and $150 \mathrm{~kg} / \mathrm{ha}$ ) as a whole plot and six wheat genotypes (BL 3623, BL 3629, BL 3872, NL 1008, NL 1055 and Vijay) as a sub-plot which were replicated three times. There was significant effect of varieties and nitrogen levels on plant height, number of spikes, thousand grain weight and grain yield in both the years. In first year, the highest grain yield of $3.35 \mathrm{t} / \mathrm{ha}$ was obtained from the application of nitrogen @ $150 \mathrm{~kg} / \mathrm{ha}$ with the genotype BL 3872 which is followed by the genotypes BL 3623 (3.15 ton/ha) and NL 1055 (3.05 ton/ha). Similarly in second year, the genotype NL 1055 gave the highest grain yield of 4.01 ton/ha followed by genotypes BL 3629 (3.83 ton/ha) and BL 3623 (3.81 ton/ha) from the application of nitrogen @ $150 \mathrm{~kg} / \mathrm{ha}$. Based on two years results, it can be concluded that $\mathrm{N}$ was a limiting factor in the productivity of wheat. Nitrogen @ $150 \mathrm{~kg}$ per ha produced higher yield and yield attributing characters. Similarly, the wheat genotypes NL 1055, BL 3629, BL 3623 and BL 3872 were superior among the genotypes.
\end{abstract}

Keywords: Nitrogen Level; Genotypes; Grain Yield; BL 3623; BL 3629; BL 3872; NL 1055

\section{Introduction}

Nitrogen fertilizer is universally accepted as a key component to high crop yield and optimum economic return. Insufficient $\mathrm{N}$ availability to wheat plants results in low yields and significantly reduced profits compared to a properly fertilized crop. Nitrogen is the most limiting nutrient in crop production and its efficient use to increase food production is more than any other input (Malhi et al., 2001). It is one of the costliest and perhaps the most crucial nutrients limiting crop yields and is a burning problem of most of the wheat growing areas of Nepal. Wheat is exhaustive crop and is highly responsive to nitrogen application. Plant growth is adversely affected due to deficiency of nitrogen as it restricts the formation of enzymes, chlorophyll and proteins necessary for growth and development (Reddy and Reddy, 2002). Not only use of fertilizer is very low in Nepal but the fertilizers are also used in imbalance way. Due to improper management, nitrogen is lost through different ways from the soil such as denitrification, runoff, leaching and weed removal which cause the low production of wheat. Therefore, proper use of $\mathrm{N}$ is critical to optimize crop yield and minimize environmental damage. It has been estimated that $40 \%$ $60 \%$ of $\mathrm{N}$-applied is taken up by wheat, which decreases as the $\mathrm{N}$-input increases, resulting in higher residual soil $\mathrm{N}$ that can be readily leached (Guarda et al., 2004). Genotypes observed superior and considered as pipeline genotypes for variety release are tested for agronomic performance in different levels of nitrogen. In view of the above findings it was imperative to conduct experiment involving different wheat genotypes with regard to their response to low and high nitrogen levels in order to obtain the potential grain yield of these varieties. Therefore, this experiment was designed to identify and recommend the appropriate dose of nitrogen for newly released varieties.

\section{Materials and Methods}

\section{Site, Treatments and Crop Management}

The experiment was laid out in split plot design: four nitrogen levels $(0,50,100$ and $150 \mathrm{~kg} / \mathrm{ha})$ as a whole plot and six wheat genotypes (BL 3623, BL 3629, BL 3872, NL 1008, NL 1055 and Vijay) as a sub-plot which were replicated three times. The crop was sown on Dec $1^{\text {st }}$ of 2012 and 2013 at the spacing of $25 \mathrm{~cm}$ between rows with 
continuous seeding. The plot size was $5 \times 2 \mathrm{~m}^{2}$ (8 rows of $5 \mathrm{~m}$ length). Urea, DAP, SSP and MOP were the source of fertilizers used for supplying nitrogen, phosphorus and potash respectively. Full dose of phosphorous and potassium fertilizers was applied at the time of land

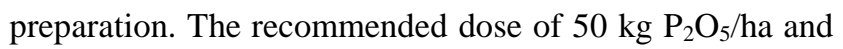
$50 \mathrm{~kg} \mathrm{~K} 2 \mathrm{O} /$ ha was applied as basal in all plots at the time of seed sowing. 1/2 dose of $\mathrm{N}$ was used at the time of seed sowing as basal dose. The remaining $1 / 2$ dose of $\mathrm{N}$ was sidedressed at CRI and maximum tillering stage.

\section{Measurement of Crop Parameters}

Data were recorded on days to heading, days to maturity, spikes $\mathrm{m}^{-2}$, grains spike ${ }^{-1}$, spike length, 1000 grain weight, biological yield, grain yield and harvest index. Number of spikes in one meter square area at four different places were counted in each subplot and converted into number of spikes $\mathrm{m}^{-2}$. Number of grains spike ${ }^{-1}$ was recorded by counting the number of grains of 5 randomly selected spikes from each subplot and average number of grains spike ${ }^{-1}$ was calculated. A random sample of 1000 grains from each treatment was collected and weighed with digital balance for 1000 grain weight. For biological yield, $5 \mathrm{~m}^{2}$ area from each sub- plot was harvested, sun dried, and weighed into $\mathrm{kgha}^{-1}$. For grain yield, the biomass of $5 \mathrm{~m}^{2}$ area from each subplot was sun dried, threshed, cleaned and grains were weighed into $\mathrm{kgha}^{-1}$.

\section{Soil Sampling and Analysis}

Soil samples were also collected from each of the selected farmers' fields described above. Each soil sample was randomly collected from the 0 to $20 \mathrm{~cm}$ deep plough layer using an auger. For this, the air-dried samples were crushed and passed through a $2 \mathrm{~mm}$ sieve. Soil $\mathrm{pH}$ was determined by a pH meter after extraction from a soil: water ratio of 1:2. Organic matter was determined using the Walkley and Black dichromate method (Nelson and Sommers, 1982) and total $\mathrm{N}$ using Kjeldhal's method (Bremner and Mulvaney, 1982) For available P determination, modified Olsen's (Olson and Sommers, 1982 ); exchangeable K (Knudsen et al., 1982) was estimated by $1 \mathrm{M}$ ammonium acetate extraction followed by flame photometric determination.

\section{Statistical Analysis}

Recorded data were compiled and tabulated in Ms-Excel. Data for each parameter over two year period was subjected to analysis of variance using a split plot design according to MSTATC (Steel and Torrie, 1980) and GENSTAT. Treatment means were compared using least significant difference (LSD) test at $\mathrm{P} \leq 0.05$.

\section{Result and Discussion}

The effect of different nitrogen levels was significant on plant height, productive tillers $/ \mathrm{m}^{2}$, thousand grain weight, biological yield and grain yield but was non-significant on heading dates, maturity dates, grains per spike, spike length and harvest index in 2012/13. The result showed that nitrogen level @ $150 \mathrm{~kg} / \mathrm{ha}$ gave higher number of tillers (281) and high biological yield (8.34 ton/ha) with respect to other levels of nitrogen but was non-significant with the application of nitrogen @ $100 \mathrm{~kg} / \mathrm{ha}$ (Table 1). But its effect was significant from the application of nitrogen @ 150 $\mathrm{kg} / \mathrm{ha}$ with the grain yield of 2.85 ton/ha.

Table 1: Plant growth, yield and yield attributing characters of wheat per hectare in interaction of the most promising wheat genotypes with different nitrogen levels conducted at NWRP, Bhairahawa, 2012/13

\begin{tabular}{|c|c|c|c|c|c|c|c|c|c|c|}
\hline Treatments & $\mathrm{DH}$ & $\mathrm{DM}$ & $\begin{array}{l}\mathrm{PH} \\
(\mathrm{cm})\end{array}$ & $\mathrm{SPM}^{2}$ & GPS & SL & TGW & GY & $\mathrm{BY}$ & $\mathrm{HI}$ \\
\hline \multicolumn{11}{|c|}{ Nitrogen level $\left(\mathrm{kg} \mathrm{ha}^{-1}\right)$} \\
\hline 0 & 86 & 118 & 71.2 & 167 & 31 & 8.7 & 45.5 & 973 & 3479 & 26.5 \\
\hline 50 & 85 & 118 & 85.2 & 212 & 33 & 9.3 & 44.3 & 1778 & 6139 & 28.4 \\
\hline 100 & 85 & 117 & 88.1 & 254 & 37 & 9.6 & 42.5 & 2311 & 7590 & 30.3 \\
\hline 150 & 85 & 118 & 87.8 & 281 & 34 & 9.9 & 40.0 & 2847 & 8340 & 34.1 \\
\hline F test of $\mathrm{A}$ & Ns & Ns & $*$ & $* *$ & Ns & Ns & $*$ & $* * *$ & $* * *$ & Ns \\
\hline LSD 0.05 & - & - & 9.9 & 50.6 & - & - & 3.3 & 205.2 & 1066 & - \\
\hline \multicolumn{11}{|l|}{ Genotypes } \\
\hline BL 3623 & 84 & 118 & 80.8 & 214 & 36 & 9.5 & 44.9 & 2203 & 6792 & 31.8 \\
\hline BL 3629 & 83 & 118 & 78.8 & 230 & 40 & 9.8 & 44.4 & 2142 & 6573 & 32.4 \\
\hline BL 3872 & 87 & 120 & 83.6 & 212 & 33 & 9.5 & 47.4 & 2146 & 6729 & 30.1 \\
\hline NL 1008 & 86 & 118 & 83.5 & 221 & 30 & 9.7 & 41.8 & 1549 & 6073 & 23.5 \\
\hline NL1055 & 86 & 118 & 83.4 & 267 & 33 & 8.7 & 36.6 & 2008 & 6271 & 30.7 \\
\hline Vijay & 84 & 117 & 88.5 & 227 & 30 & 9.2 & 43.5 & 1817 & 5885 & 30.5 \\
\hline F test of B & $* * *$ & Ns & $* * *$ & $*$ & ns & $* * *$ & $* * *$ & $* * *$ & ns & $* *$ \\
\hline LSD 0.05 & 1.6 & 2.0 & 3.1 & 33.0 & 6.8 & 0.5 & 3.0 & 155.0 & 631.5 & 4.4 \\
\hline \multicolumn{11}{|l|}{ Interaction } \\
\hline$F$ test of $A^{*} B$ & $\mathrm{Ns}$ & $\mathrm{Ns}$ & Ns & Ns & Ns & Ns & Ns & Ns & Ns & Ns \\
\hline $\mathrm{CV}(\%)$ & 2.2 & 2.1 & 4.5 & 17.5 & 24.5 & 5.9 & 8.5 & 19.2 & 12.0 & 17.7 \\
\hline
\end{tabular}


Table 2: Plant growth, yield and yield attributing characters of wheat per hectare in interaction of the most promising wheat genotypes with different nitrogen levels conducted at NWRP, Bhairahawa, 2013/14

\begin{tabular}{|c|c|c|c|c|c|c|c|c|c|c|}
\hline Treatments & $\mathrm{DH}$ & $\mathrm{DM}$ & $\begin{array}{l}\mathrm{PH} \\
(\mathrm{cm})\end{array}$ & $\mathrm{SPM}^{2}$ & GPS & SL & TGW & GY & $\mathrm{BY}$ & HI \\
\hline \multicolumn{11}{|c|}{ Nitrogen level $\left(\mathrm{kg} \mathrm{ha}^{-1}\right)$} \\
\hline 0 & 80 & 115 & 84.6 & 190 & 30 & 10.7 & 50.3 & 1760 & 5756 & 23.4 \\
\hline 50 & 80 & 115 & 91.4 & 208 & 33 & 11.4 & 48.3 & 2665 & 7211 & 27.1 \\
\hline 100 & 80 & 115 & 92.4 & 222 & 35 & 11.3 & 46.7 & 3315 & 8511 & 28.1 \\
\hline 150 & 81 & 115 & 91.4 & 233 & 39 & 11.4 & 44.7 & 3699 & 9167 & 28.8 \\
\hline F test of $\mathrm{A}$ & Ns & Ns & $* *$ & $*$ & $* *$ & $\mathrm{Ns}$ & $* * *$ & $* * *$ & $* * *$ & $* * *$ \\
\hline LSD 0.05 & 1.1 & 0.5 & 2.8 & 23.1 & 4.2 & 0.9 & 1.7 & 342.9 & 862.7 & 1.8 \\
\hline \multicolumn{11}{|l|}{ Genotypes } \\
\hline BL 3623 & 78 & 115 & 87.4 & 169 & 37 & 11.6 & 49.4 & 2953 & 7567 & 27.8 \\
\hline BL 3629 & 79 & 114 & 86.4 & 200 & 36 & 11.5 & 50.8 & 2954 & 7367 & 28.3 \\
\hline BL 3872 & 85 & 117 & 91.7 & 208 & 35 & 11.6 & 51.4 & 2897 & 9100 & 24.0 \\
\hline NL 1008 & 82 & 116 & 90.6 & 167 & 37 & 11.9 & 44.5 & 2463 & 7167 & 24.6 \\
\hline NL1055 & 80 & 114 & 89.1 & 307 & 38 & 10.0 & 38.6 & 2990 & 7750 & 27.4 \\
\hline Vijay & 76 & 114 & 94.5 & 228 & 26 & 10.6 & 50.4 & 2901 & 7017 & 29.0 \\
\hline F test of B & $* * *$ & $* * *$ & $* * *$ & $* * *$ & $* * *$ & $* * *$ & $* * *$ & $* * *$ & $* * *$ & $* * *$ \\
\hline $\begin{array}{l}\text { LSD } 0.05 \\
\text { Interaction }\end{array}$ & 1.3 & 0.4 & 2.0 & 32.7 & 3.6 & 0.6 & 1.5 & 209.1 & 487.7 & 1.4 \\
\hline F test of $A * B$ & Ns & $\mathrm{Ns}$ & Ns & Ns & Ns & Ns & $* * *$ & $\mathrm{Ns}$ & Ns & $* * *$ \\
\hline LSD 0.05 & 2.5 & 0.8 & 4.3 & 62.4 & 7.4 & 1.4 & 3.0 & 479.2 & 1154 & 2.9 \\
\hline $\mathrm{CV}(\%)$ & 2.0 & 0.4 & 2.7 & 18.6 & 12.7 & 6.6 & 3.7 & 8.9 & 7.7 & 6.1 \\
\hline
\end{tabular}

Similarly, there was significant effect of the most promising wheat genotypes on heading dates, plant height, spike length, productive tillers per square meter, thousand grain weight, grain yield and harvest index. The analysis showed that highest grain yield of $2203 \mathrm{~kg} / \mathrm{ha}$ was obtained from the wheat genotype BL 3623 which was followed by the genotype BL 3872 (2146 kg/ha) and BL 3629 (2142 kg/ha).

The results showed significant differences among the different nitrogen applied on plant height, productive tillers $/ \mathrm{m}^{2}$, grains per spike, thousand grain weight, biological yield, harvest index and grain yield but was non significant on heading dates, maturity dates and spike length in 2013/14 (Table 2). The data revealed that nitrogen level @ $150 \mathrm{~kg} / \mathrm{ha}$ gave higher number of tillers (233), grain per spike (39), grain yield (3.7 ton/ha) and high biological yield $(9.17$ ton/ha) with respect to other levels of nitrogen but was non-significant with the application of nitrogen @ 100 $\mathrm{kg} / \mathrm{ha}$.

Similarly, there was significant effect of the most promising wheat genotypes on heading dates, maturity dates, plant height, spike length, productive tillers per square meter, grains per spike, thousand grain weight, grain yield, biological yield and harvest index. The analysis showed that highest grain yield of $2990 \mathrm{~kg} / \mathrm{ha}$ was obtained from the wheat genotype NL 1055 which was followed by the genotype BL 3629 (2954 kg/ha) and BL 3623 (2953 kg/ha). The interaction effect of nitrogen levels with different genotypes was non-significant in both years.
The combined two years analysis of the data revealed that there was significant effect of different nitrogen levels was significant on plant height, productive tillers $/ \mathrm{m}^{2}$, thousand grain weight, biological yield, grains per spike, spike length, harvest index and grain yield but was non-significant on heading dates and maturity dates. The result showed that nitrogen level@150 kg/ha gave higher number of tillers (257), grain per spike (37) and high biological yield (8.75 ton/ha) with respect to other levels of nitrogen but was nonsignificant with the application of nitrogen @ $100 \mathrm{~kg} / \mathrm{ha}$ (Table 3). But its effect was significant from the application of nitrogen@150 kg/ha with the grain yield of 3.27 ton/ha. Geleto et al. (1995) reported that spike numbers and grain weight were increased with high level of nitrogen. Similarly, Singh and Uttam (1992) recorded increased grain yield with increase in nitrogen level which is similar with the finding of the two years experiment.

Similarly, the results showed significant differences among the different wheat genotypes on all the yield and yield attributing characters. The highest grain yield of $2578 \mathrm{~kg} / \mathrm{ha}$ was obtained from the wheat genotype BL 3623 which was followed by the genotype BL $3629(2548 \mathrm{~kg} / \mathrm{ha})$ and BL 3872 (2521 kg/ha). The yield and yield attributing characters was superior and higher in second year of experiment as compared to first year. The reason may be the higher rainfall during heading period (in 2013) which caused logging in the experiment field resulting lower yield. 
Table 3: Plant growth, yield and yield attributing characters of wheat per hectare in interaction of the most promising wheat genotypes with different nitrogen levels at NWRP, Bhairahawa during two growing seasons

\begin{tabular}{|c|c|c|c|c|c|c|c|c|c|c|}
\hline Treatments & $\mathrm{DH}$ & $\mathrm{DM}$ & $\begin{array}{l}\mathrm{PH} \\
(\mathrm{cm})\end{array}$ & $\mathrm{SPM}^{2}$ & GPS & SL & TGW & GY & BY & $\mathrm{HI}$ \\
\hline \multicolumn{11}{|c|}{ Nitrogen level $\left(\mathrm{kg} \mathrm{ha}^{-1}\right)$} \\
\hline 0 & 83 & 116 & 77.9 & 178 & 30 & 9.7 & 47.9 & 1366 & 4617 & 25.0 \\
\hline 50 & 83 & 117 & 88.3 & 210 & 33 & 10.3 & 46.3 & 2222 & 6675 & 27.8 \\
\hline 100 & 83 & 116 & 90.3 & 238 & 36 & 10.5 & 44.6 & 2813 & 8051 & 29.2 \\
\hline 150 & 83 & 117 & 89.6 & 257 & 37 & 10.7 & 42.3 & 3273 & 8753 & 31.5 \\
\hline F test of $A$ & Ns & Ns & $* *$ & $* * *$ & $*$ & $*$ & $* * *$ & $* * *$ & $* * *$ & $* * *$ \\
\hline LSD 0.05 & 1.2 & 0.7 & 4.9 & 25.4 & 3.6 & 0.5 & 1.6 & 330.4 & 788.3 & 2.0 \\
\hline \multicolumn{11}{|l|}{ Genotypes } \\
\hline BL 3623 & 81 & 116 & 84.1 & 191 & 37 & 10.6 & 47.2 & 2578 & 7179 & 29.8 \\
\hline BL 3629 & 81 & 116 & 82.6 & 215 & 38 & 10.6 & 47.6 & 2548 & 6970 & 30.4 \\
\hline BL 3872 & 86 & 118 & 87.7 & 210 & 34 & 10.6 & 49.4 & 2521 & 7915 & 27.0 \\
\hline NL 1008 & 84 & 117 & 87.0 & 194 & 34 & 10.8 & 43.1 & 2006 & 6620 & 24.0 \\
\hline NL1055 & 83 & 116 & 86.3 & 287 & 32 & 9.4 & 37.6 & 2499 & 7010 & 29.0 \\
\hline Vijay & 80 & 116 & 91.5 & 228 & 28 & 9.9 & 46.9 & 2359 & 6451 & 29.8 \\
\hline F test of B & $* * *$ & $* * *$ & $* * *$ & $* * *$ & $* * *$ & $* * *$ & $* * *$ & $* * *$ & $* * *$ & $* * *$ \\
\hline LSD 0.05 & 1.2 & 1.1 & 1.9 & 22.3 & 3.7 & 0.4 & 1.6 & 185.0 & 328.0 & 2.2 \\
\hline \multicolumn{11}{|l|}{ Year } \\
\hline 2013 & 85 & 118 & 83.1 & 229 & 34 & 9.4 & 43.1 & 1977 & 6387 & 29.8 \\
\hline 2014 & 80 & 115 & 90.0 & 213 & 34 & 11.2 & 47.5 & 2860 & 7661 & 26.9 \\
\hline$F$ test of $A * B$ & $* * *$ & $* * *$ & $* * *$ & $*$ & Ns & $* * *$ & $* * *$ & $* * *$ & $* * *$ & $* * *$ \\
\hline LSD 0.05 & 0.5 & 0.6 & 1.5 & 14.1 & 2.4 & 0.3 & 1.0 & 141.8 & 327.1 & 1.6 \\
\hline \multicolumn{11}{|l|}{ Interaction } \\
\hline F test of $A^{*} B^{*}$ Year & Ns & Ns & Ns & Ns & Ns & Ns & Ns & Ns & Ns & Ns \\
\hline LSD 0.05 & 2.9 & 2.9 & 7.4 & 66.0 & 11.0 & 1.4 & 4.7 & 648.2 & 1425.7 & 6.9 \\
\hline $\mathrm{CV}(\%)$ & 1.9 & 1.5 & 5.2 & 19.1 & 21.3 & 9.9 & 6.7 & 17.5 & 13.9 & 16.7 \\
\hline
\end{tabular}

Table 4: Interaction effects of nitrogen and varieties on grain yield of wheat in year 2012/13 and $2013 / 14$

\begin{tabular}{|c|c|c|c|c|c|c|c|c|c|c|c|c|}
\hline \multirow{3}{*}{ Treatments } & \multicolumn{12}{|c|}{ Grain yield of wheat } \\
\hline & \multicolumn{4}{|c|}{2013} & \multicolumn{4}{|c|}{2014} & \multicolumn{4}{|c|}{ Combined } \\
\hline & $\mathrm{N}_{0}$ & $\mathrm{~N}_{2}$ & $\mathrm{~N}_{3}$ & $\mathrm{~N}_{4}$ & $\mathrm{~N}_{0}$ & $\mathrm{~N}_{2}$ & $\mathrm{~N}_{3}$ & $\mathrm{~N}_{4}$ & $\mathrm{~N}_{0}$ & $\mathrm{~N}_{2}$ & $\mathrm{~N}_{3}$ & $\mathrm{~N}_{4}$ \\
\hline BL 3623 & 1.30 & 1.68 & 2.68 & 3.15 & 1.98 & 2.59 & 3.43 & 3.81 & 1.64 & 2.14 & 3.06 & 3.48 \\
\hline BL 3629 & 1.23 & 2.25 & 2.32 & 2.77 & 1.85 & 2.53 & 3.61 & 3.83 & 1.54 & 2.39 & 2.96 & 3.30 \\
\hline BL 3872 & 0.87 & 1.75 & 2.62 & 3.35 & 2.02 & 2.86 & 3.26 & 3.45 & 1.44 & 2.31 & 2.94 & 3.40 \\
\hline NL 1008 & 0.61 & 1.42 & 1.86 & 2.32 & 1.12 & 2.32 & 2.96 & 3.46 & 0.86 & 1.87 & 1.87 & 2.89 \\
\hline NL 1055 & 0.89 & 2.22 & 1.87 & 3.05 & 1.74 & 2.84 & 3.37 & 4.01 & 1.32 & 2.53 & 2.53 & 3.53 \\
\hline Vijay & 0.94 & 1.35 & 2.53 & 2.45 & 1.85 & 2.85 & 3.28 & 3.63 & 1.40 & 2.10 & 2.10 & 3.04 \\
\hline $\mathrm{F}$ test of $\mathrm{A} \times \mathrm{B}$ & \multicolumn{4}{|c|}{ Ns } & \multicolumn{4}{|c|}{ Ns } & \multicolumn{4}{|c|}{ Ns } \\
\hline LSD 0.05 & \multicolumn{4}{|c|}{0.71} & \multicolumn{4}{|c|}{0.48} & \multicolumn{4}{|c|}{0.44} \\
\hline $\mathrm{CV}(\%)$ & \multicolumn{4}{|c|}{19.2} & \multicolumn{4}{|c|}{8.9} & \multicolumn{4}{|c|}{17.5} \\
\hline
\end{tabular}

In first year, the highest grain yield of $3.35 \mathrm{t} / \mathrm{ha}$ was obtained from the application of nitrogen @ $150 \mathrm{~kg} / \mathrm{ha}$ with the genotype BL 3872 which is followed by the genotypes BL 3623 (3.15 ton/ha) and NL 1055 (3.05 ton/ha). Similarly in second year, the genotype NL 1055 gave the highest grain yield of 4.01 ton/ha followed by genotypes BL 3629 (3.83 ton/ha) and BL 3623 (3.81 ton/ha) from the application of nitrogen@150 kg/ha. (Table 4)

\section{Conclusion}

It can be summarized from these results that four varieties (BL 3623, BL 3629, BL 3872 and NL 1055) performed well and showed positive response to the high dose of nitrogen
(@150 kg/ha) under the climatic conditions of Bhairahawa (NWRP), Nepal. It can be assumed that $\mathrm{N}$ was a limiting factor in the productivity of wheat. So, Nitrogen can be applied at high rate of $150 \mathrm{~kg} / \mathrm{ha}$ to any wheat variety without having adverse effect on the recommended yield.

\section{Acknowledgment}

The authors want to express their sincere gratitude to Wheat Coordinator, NWRP, Bhairahawa for providing facilities and proper guidance during the course of this research. The author is grateful to NARC for providing research fund. Thanks also goes to the present staffs of NWRP without 
whose assistance, the experiment would not have reached this stage.

\section{References}

Geleto T, Tanner DG, Mamo T, and Gebeyehu G (1995) Response of rain fed bread and durum wheat to source level and timing of nitrogen fertilizer on two Ethiopian vertisole S. I. yield and yield components. Comm. Soil Sci. Plant Analysis 26: 1773-1794.

Guarda G, Padovan S, and Delogu G (2004) Grain Yield, Nitrogen-Use Efficiency and Baking Quality of Old and Modern Italian Bread-Wheat Cultivars Grown at Different
Nitrogen Levels. European Journal of Agronomy. 21(2): 181-192.

Malhi SS, Grant CA, Johnston AM and Gill KS (2001) Nitrogen Fertilization and Management for No-Till Cereal Production in the Canadian Great Plains: A Review. Soil and Tillage Research. 60(4):101-122.

Reddy TY and Reddy GHS (2002) Princilples of Agronomy. Kalyani Publishers, New Delhi, India.

Singh VPN and Uttam SK (1992) Response of wheat cultivars to different $\mathrm{N}$ levels under early sown conditions. Crop Res. 5: $82-86$.

Steel RGD, and Torrie JH (1980) "Principles and Procedures of Statistics” McGraw Hill Book Co. Inc., New York 